\title{
Evaluation of HIV voluntary counselling and testing services in Egypt. Part 1: client satisfaction
}

\author{
I.A. Kabbash, ${ }^{7}$ N.M. Hassan, ${ }^{1}$ A.N. Al-Nawawy, ${ }^{2}$ A.A. Attalla ${ }^{7}$ and S.I. Mekheimer ${ }^{3}$
}

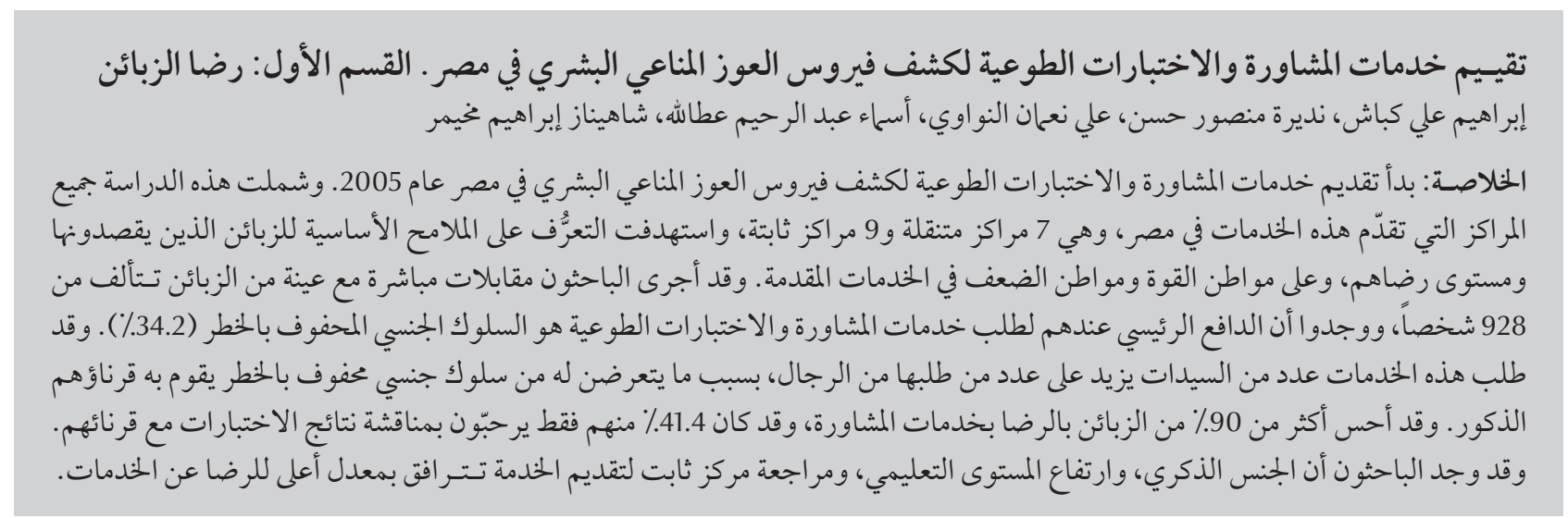

ABSTRACT HIV voluntary counselling and testing (VCT) services were launched in Egypt in 2005. A study of all functioning VCT centres in Egypt (7 mobile and 9 fixed) aimed to determine the profile of clients and their level of satisfaction to identify strengths and weaknesses in the service. In direct interviews with a sample of 928 clients, the main motive for seeking VCT was risky sexual behaviour (34.2\%). More females than males sought services because of partners' risky sexual behaviour. More than $90 \%$ of the clients were satisfied with the counselling service. Only $41.4 \%$ were willing to discuss the test results with their partners. Male sex, higher education level and attendance at fixed VCT centres were associated with higher satisfaction.

Évaluation des services de conseil et de dépistage volontaires pour le VIH/sida en Égypte. Première partie : satisfaction des usagers

RÉSUMÉ Les services de conseil et de dépistage volontaires pour le VIH/sida ont été proposés en Égypte en 2005. Une étude portant sur l'ensemble des centres égyptiens les offrant, soit sept centres mobiles et neufs fixes, a été réalisée pour déterminer le profil des usagers et leur niveau de satisfaction, afin d'identifier les points forts et les points faibles de ces services. Les entretiens directs effectués avec un échantillon de 928 usagers ont montré que la demande de services de conseil et de dépistage volontaires pour le VIH/sida était principalement motivée par des comportements sexuels à risque (34,2\%). Les femmes faisaient davantage appel à ces services que les hommes en raison du comportement à risque de leur partenaire. Plus de $90 \%$ des usagers étaient satisfaits du service de conseil. Seuls $41,4 \%$ d'entre eux se disaient prêts à discuter du résultat des tests avec leurs partenaires. Le niveau de satisfaction le plus élevé était associé au sexe masculin, à un niveau d'éducation supérieure et à la fréquentation de centres fixes de conseil et de dépistage volontaires.

'Department of Public Health and Community Medicine, Tanta Faculty ofMedicine, Tanta, Egypt (Correspondence to I.A. Kabbash: iafkabbash@) gmail.com).

${ }^{2}$ Department of Public Health and Community Medicine, Al-Azhar Faculty of Medicine, Damietta Branch, Damietta, Egypt.

${ }^{3}$ Department of Health Education, Theodor Bilharz Research Institute, Cairo, Egypt.

Received: 02/04/08; accepted: 03/06/08 


\section{Introduction}

The acquired immunodeficiency syndrome (AIDS) has killed more than 25 million people since 1981. Despite recent improvement in access to care and antiretroviral treatment in many regions of the world, the AIDS epidemic claimed 3.1 million lives in 2005. The total number of people living with the human immunodeficiency virus (HIV) reached an estimated 40.3 million in that year [1].

Knowledge of a person's HIV infection status strengthens prevention efforts by encouraging infected persons to avoid transmission to others and motivating those who are not infected to protect themselves through risk reduction strategies and behaviour change. HIV counselling and testing can lead to a reduction in the number of sexual partners, increased condom use, fewer sexually transmitted infections (STI) and safer injection practices [2].

The first voluntary counselling and testing (VCT) centre in Egypt was launched in January 2005. VCT allows clients the opportunity to utilize anonymous pre-test and post-test counselling services when considering an HIV test and to be linked to a range of care and support services that meet their needs. The procedures for conducting VCT should be reviewed and updated regularly to improve the quality of services provided [3]. To expand these services in Egypt, there is a need to determine clients' level of satisfaction and to overcome weaknesses in the service. There is also a need to determine whether the expansion should be in the form of fixed or mobile centres.

The objectives of this study were: to identify the sociodemographic characteristics of clients using VCT services; to determine their level of satisfaction with VCT and identify strengths and weaknesses in the service; to identify the rate of use of VCT services; and to compare the services provided by fixed and mobile centres to help in the future planning of new centres.

\section{Methods}

This was a cross-sectional interview study of clients attending VCT centres throughout Egypt.

\section{Study setting}

At the time of the study VCT services were provided by 7 fixed and 9 mobile centres distributed in 12 governorates of Egypt.

In Egypt fixed VCT centres are located within buildings of the Ministry of Health and provide counselling and testing for HIV only. Labelling the centres as "centres for voluntary counselling and testing", without mentioning the word AIDS, aims to ensure the confidentiality of services and to avoid stigmatizing visitors. The mobile VCT centres are in the form of mobile vehicles comprising 3 sections: the first for the driver, the second for the counselling session which is conducted in privacy where only the counsellor and the clients are present and the third section is for laboratory testing. Each section has a private entrance. To avoid the stigma of attending the mobile services, they were established to provide counselling services for 5 health problems: tuberculosis, hepatitis $B$, hepatitis C, HIV/AIDS and drug abuse. The laboratory provides testing services for HIV and viral hepatitis B and C. The mobile centres are moved according to a prescheduled programme.

The working days of these centres are Sunday to Thursday. All services are free of charge and performed anonymously. The majority of service providers are males. The study was conducted during the period from July 2006 to end of June 2007. All centres that had been functioning for at least 6 months by the time of the study were visited and included in the study. This duration was selected to ensure that the centre had been functioning for a sufficiently long period to determine the level of satisfaction of clients.

\section{Sample}

The study subjects were clients served by all VCT centres functioning for at least 6 months by the time of the study. The sample size was determined using Epi-Info statistical software, considering the power of the study at $80 \%$ with an alpha error of $5 \%$ and beta error of $20 \%$. The calculated sample size was found to be more than 800 . The average number of clients served during a 1-week period was found to be around 50 clients based on reports of VCT centres presented to the Ministry of Health and Population at the end of 2005.

At each centre, at least 50 clients were interviewed on days covering every working day of the week. For mobilecentres, the interviewees were selected from at least 5 different localities. Selection of clients was performed using systematic sampling where every second client was chosen. This was based on the results of a pilot study showing that the duration of counselling was 15-20 minutes and the duration of interviews was 30-40 minutes. The place of interviewing was selected to ensure confidentiality and the comfort of the interviewees away from the personnel of the VCT centres to avoid any bias in data collection. In 2 fixed centres we failed to collect data from 50 clients due to the low attendance rate. The total number of clients interviewed in these 2 centres was 45 (the target should be 100). The missing 55 clients were taken from 3 other fixed centres. The refusal rate was minimal, ranging between $1 \%$ and $4 \%$ at different centres.

\section{Data collection}

A predesigned questionnaire sheet was used to study the satisfaction of clients with the provided service. The questionnaire sheet included the following data: sociodemographic data; service required and motive for seeking it; and 
source of information about the VCT service. A checklist was used for evaluation of the level of clients' satisfaction with the offered service using a list of functions that should be fulfilled during the counselling session. The total number of questions in the checklist was 24 (scored 1 for positive answer and 0 for negative one: total score 24). The level of satisfaction was calculated as a percentage of the total score. Data collection was performed through direct interviews with the study participants.

The content validity of the questionnaire was reviewed by 3 experts and 5 peer reviewers. A pilot study including 30 individuals (not included in the study sample) was carried out to ensure its suitability for data collection relevant to the study design and objectives. Reliability was assessed by test-retest to eliminate inter-rater and intra-rater bias. The interviewers were trained before the start of the study on interviewing skills and how to complete the questionnaires.

The interviewees were informed of the aims of the study and given guarantees about the confidentiality of the collected data. A verbal witnessed consent was obtained before data collection.
No pressure of any kind was imposed on interviewees to participate in the study. Confidentiality and comfort were secured at the place of the study.

\section{Data analysis}

The collected data were statistically analysed using SPSS statistical software, version 12 . The mean and standard deviation (SD) were used for quantitative variables and the $t$-test was used for statistical analysis. For categorical variables, the number and percentage distribution were calculated and chi-squared tests used for analysis. Fisher exact test was used when the chi-squared test was not appropriate. The level of significance was $P<0.05$.

\section{Results}

\section{Workload of centres}

The rate of clients served at mobile centres was 262.1 clients per month per centre, ranging from 176.2 to 351.8 per month at different centres. On the other hand, the rate in fixed centres was much lower (33.1 clients per month per centre), and ranged from 3.9 to 28.0 per month in 6 out of the 7 fixed centres, while in the Red Sea it was exceptionally high at 149.7 per month. Excluding the Red Sea centre, the rate of clients served by fixed centres was 13.7 per month per centre (Table 1).

\section{Background characteristics of clients}

The age range of the majority of studied clients $(77.0 \%)$ was $20-40$ years. The mean age of clients in fixed centres [28.6 (SD 6.7) years] was significantly lower than that in the mobile ones [30.4 (SD $9.8)$ years $](P=0.001)$. The majority of served clients were males (81.8\%). More females visited the mobile centres (20.3\%) than fixed ones (14.6\%) ( $P=$ 0.028 ). Skilled workers were the main occupational group among served clients (43.1\%). In mobile centres significantly more manual workers, students and employees were served compared with clients at fixed centres $(P<0.001)$. Nearly two-thirds of the clients overall had secondary or university education (67.4\%). However, in mobile centres, significantly more clients were illiterate $(7.9 \%)$ or could just read and write (10.1\%) compared with clients at fixed centres (2.9\% and $2.3 \%$ respectively) $(P<0.001)$. Single clients comprised 48.8\% (Table 2).

\begin{tabular}{|c|c|c|c|c|}
\hline \multirow[t]{2}{*}{ Governorate } & \multicolumn{2}{|c|}{ Mobile VCT } & \multicolumn{2}{|c|}{ Fixed VCT } \\
\hline & No. of clients & Rate $^{a}$ & No. of clients & Rate $^{a}$ \\
\hline Cairo & 3628 & 302.3 & 336 & 28.0 \\
\hline Aswan & 3459 & 288.3 & 47 & 3.9 \\
\hline Gharbia & 4221 & 351.8 & 118 & 9.8 \\
\hline Red Sea & 2619 & 218.3 & 1796 & 149.7 \\
\hline Alexandria & 2806 & 233.8 & - & - \\
\hline South Sinai & 2976 & 248.0 & - & - \\
\hline Luxor & 3047 & 253.9 & - & - \\
\hline Fayoum & 2114 & 176.2 & - & - \\
\hline Minya & 3440 & 286.7 & - & - \\
\hline Beni Seuif & - & - & 294 & 24.5 \\
\hline Kafr El-Sheikh & - & - & 117 & 9.7 \\
\hline Sharqia & - & - & 74 & 6.2 \\
\hline Total & 28310 & $262.1^{\mathrm{a}}$ & 2782 & 33.1 \\
\hline
\end{tabular}

${ }^{a}$ Rate per month per centre. 


\begin{tabular}{|c|c|c|c|c|c|c|c|c|}
\hline \multirow[t]{2}{*}{ Demographic variable } & \multicolumn{2}{|c|}{ Mobile VCT $(n=585)$} & \multicolumn{2}{|c|}{ Fixed VCT $(n=343)$} & \multicolumn{2}{|c|}{ Total $(n=928)$} & \multirow[t]{2}{*}{ Test statistic } & \multirow[t]{2}{*}{$P$-value } \\
\hline & No. & $\%$ & No. & $\%$ & No. & $\%$ & & \\
\hline \multicolumn{9}{|l|}{ Age (years) } \\
\hline$<20$ & 66 & 11.3 & 21 & 6.1 & 87 & 9.4 & & \\
\hline $20-$ & 254 & 43.4 & 190 & 55.4 & 444 & 47.8 & & \\
\hline $30-$ & 158 & 27.0 & 113 & 32.9 & 271 & 29.2 & & \\
\hline $40-$ & 81 & 13.8 & 16 & 4.7 & 97 & 10.5 & & \\
\hline $50-65$ & 26 & 4.5 & 3 & 0.9 & 29 & 3.1 & & \\
\hline Mean (SD) age & \multicolumn{2}{|c|}{$30.4(9.8)$} & \multicolumn{2}{|c|}{$28.6(6.7)$} & \multicolumn{2}{|c|}{$29.9(8.8)$} & $t=3.77$ & 0.001 \\
\hline Sex & & & & & & & $\chi^{2}=4.82$ & 0.028 \\
\hline Male & 466 & 79.7 & 293 & 85.4 & 759 & 81.8 & & \\
\hline Female & 119 & 20.3 & 50 & 14.6 & 169 & 18.2 & & \\
\hline Occupation & & & & & & & $\chi^{2}=23.42$ & 0.001 \\
\hline Manual worker & 56 & 9.6 & 22 & 6.4 & 78 & 8.4 & & \\
\hline Skilled worker & 235 & 40.2 & 165 & 48.1 & 400 & 43.1 & & \\
\hline Employee & 79 & 13.5 & 29 & 8.5 & 108 & 11.6 & & \\
\hline Professional & 68 & 11.6 & 59 & 17.2 & 127 & 13.7 & & \\
\hline Student & 95 & 16.2 & 34 & 9.9 & 129 & 13.9 & & \\
\hline Housewife & 33 & 5.6 & 17 & 5.0 & 50 & 5.4 & & \\
\hline Unemployed & 19 & 3.2 & 17 & 5.0 & 36 & 3.9 & & \\
\hline Educational level & & & & & & & $\chi^{2}=33.37$ & 0.001 \\
\hline Illiterate & 46 & 7.9 & 10 & 2.9 & 56 & 6.0 & & \\
\hline Read \& write & 59 & 10.1 & 8 & 2.3 & 67 & 7.2 & & \\
\hline Primary & 112 & 19.1 & 67 & 19.6 & 179 & 19.4 & & \\
\hline Secondary & 195 & 33.3 & 129 & 37.6 & 324 & 34.9 & & \\
\hline University & 173 & 29.6 & 129 & 37.6 & 302 & 32.5 & & \\
\hline Marital status & & & & & & & $\chi^{2}=4.58$ & 0.206 \\
\hline Married & 261 & 44.6 & 167 & 48.7 & 428 & 46.1 & & \\
\hline Single & 288 & 49.2 & 165 & 48.1 & 453 & 48.8 & & \\
\hline Divorced & 25 & 4.3 & 8 & 2.3 & 33 & 3.6 & & \\
\hline Widowed & 11 & 1.9 & 3 & 0.9 & 14 & 1.5 & & \\
\hline
\end{tabular}

$S D=$ standard deviation.

\section{Motives for seeking VCT}

The main motives for seeking VCT services were having risky sexual behaviour $(34.2 \%)$ or a previous blood transfusion (22.3\%). Planning to get married and a history of blood transfusion were reported by significantly more clients in mobile centres than fixed centres $(P=$ 0.041 and $P<0.001$ respectively). On the other hand, having a new sexual partner was reported by $19.8 \%$ of clients in fixed centres and this was significantly higher than the rate of $10.4 \%$ among clients of mobile VCT centres $(P<$ 0.001).
The main sources of information about VCT centres were relatives/ friends (32.7\%), posters (24.5\%), health care workers $(23.4 \%)$ and lectures (20.0\%). Radio, newspapers and the telephone hotlines were the lowest sources (1.9\%-2\%). In mobile centres, significantly more clients reported lectures and posters as sources of information than did clients of fixed centres $(P<$ $0.001)$. On the other hand, sex partners and relatives or friends and hotlines were reported significantly more by clients of fixed centres than mobile ones (Table 3).

\section{Male/female differences}

Males reported seeking VCT services most commonly because of having risky sexual behaviour (39.3\%), being injecting drug users (17.0\%) or having a new sexual partner $(16.1 \%)$ and these rates were significantly higher than among females $(11.2 \%, 1.2 \%$ and $4.1 \%$ respectively) $(P<0.001)$. Significantly more females sought VCT services because their partners were suspected of having risky sexual behaviours (33.7\%) than did males $(7.4 \%)(P<0.001)$.

The sources of information about VCT service were nearly the same 
among females and males except that significantly more males $(21.5 \%)$ reported another VCT client as their source of information as compared with females $(10.1 \%)(P<0.001)($ Table 4$)$.

\section{Services received}

Most of the clients at centres received counselling and testing (90.5\%). The percentage of those receiving counselling only was significantly higher in mobile centres (11.8\%) compared with fixed ones $(5.5 \%)(P=0.002)$. Almost all the clients were counselled in an individual setting (96.9\%). Significantly more clients were served in couples at fixed centres $(5.2 \%)$ than those in mobile ones $(1.9 \%)(P=0.004)$. The majority of the studied clients had not been tested for HIV before visiting the VCT (89.9\%). This percentage was significantly higher in mobile centres compared with fixed centres (95.0\% and $81.0 \%$ respectively $)(P<0.001)$. At fixed centres, $92.4 \%$ reported the availability of information and educational materials and this was significantly higher than at mobile centres $(71.6 \%)(P<0.001)$. However, $95.4 \%$ of clients at mobile centres reported receiving health education about HIV/AIDS during waiting sessions, which was significantly higher than $62.1 \%$ among clients at fixed centres $(P<0.001)$ (Table 5$)$.

\section{Satisfaction with services}

Age and marital status did not affect clients' satisfaction scores. However, the mean percentage level of satisfaction of males [90.8\% (SD 8.0\%)] was significantly higher than that of females $[89.0 \%(\mathrm{SD} 10.4 \%)](P=0.031)$. The mean percentage satisfaction among clients with secondary and university education [91.1\% (SD 8.2\%)] was significantly higher than among illiterate or primary educated clients [89.2\% (SD 9.0\%)] $(P=0.002)$. Satisfaction was also significantly higher among clients served at fixed VCT centres [94.2\% (SD 6.2\%)] compared with mobile centres $[88.3 \%($ SD $8.9 \%)](P<0.001)$ (Table 6).

Table 7 shows that $98.7 \%$ of all clients reported satisfaction with different steps of the counselling service. Only $57.9 \%$ of the studied clients reported talking with the counsellor about issues related to previous or current HIV testing and only $41.4 \%$ said they were willing to discuss the test results with their partners. More than half reported (59.8\%) that they had learned something new about HIV/AIDS from the video films or brochures at the VCT;

\begin{tabular}{|c|c|c|c|c|c|c|c|c|}
\hline \multirow[t]{2}{*}{ Variable } & \multicolumn{2}{|c|}{ Mobile VCT $(n=585)$} & \multicolumn{2}{|c|}{ Fixed VCT $(n=343)$} & \multicolumn{2}{|c|}{ Total $(n=928)$} & \multirow[t]{2}{*}{$x^{2}$-value } & \multirow[t]{2}{*}{$P$-value } \\
\hline & No. & $\%$ & No. & $\%$ & No. & $\%$ & & \\
\hline \multicolumn{9}{|l|}{ Motives for using the service } \\
\hline Risky sexual behaviour & 188 & 32.1 & 129 & 37.6 & 317 & 34.2 & 2.88 & 0.090 \\
\hline Previous blood transfusion & 157 & 26.8 & 50 & 14.6 & 207 & 22.3 & 18.75 & 0.001 \\
\hline Planning to get married & 101 & 17.3 & 42 & 12.2 & 143 & 15.4 & 4.18 & 0.041 \\
\hline Injecting drug user & 84 & 14.4 & 47 & 13.7 & 131 & 14.1 & 0.06 & 0.782 \\
\hline New sexual partner & 61 & 10.4 & 68 & 19.8 & 129 & 13.9 & 15.96 & 0.001 \\
\hline $\begin{array}{l}\text { Partner has risky sexual } \\
\text { behaviour }\end{array}$ & 74 & 12.6 & 39 & 11.4 & 113 & 12.2 & 0.33 & 0.565 \\
\hline Referred by health worker & 43 & 7.4 & 37 & 10.8 & 80 & 8.6 & 3.24 & 0.072 \\
\hline Previous HIV testing & 23 & 3.9 & 14 & 4.1 & 37 & 4.0 & 0.01 & 0.910 \\
\hline Other & 68 & 11.6 & 22 & 6.4 & 90 & 9.7 & 6.70 & 0.010 \\
\hline \multicolumn{9}{|c|}{ Source of information about VCT } \\
\hline Relative/friend & 159 & 27.2 & 144 & 42.0 & 303 & 32.7 & 21.55 & 0.001 \\
\hline Poster & 184 & 31.5 & 43 & 12.5 & 227 & 24.5 & 41.87 & 0.001 \\
\hline Health worker & 149 & 25.5 & 68 & 19.8 & 217 & 23.4 & 3.85 & 0.050 \\
\hline Lecture & 177 & 30.3 & 9 & 2.6 & 186 & 20.0 & 103.00 & 0.001 \\
\hline Another VCT client & 121 & 20.7 & 59 & 17.2 & 180 & 19.4 & 1.68 & 0.195 \\
\hline Pamphlet & 86 & 14.7 & 64 & 18.7 & 150 & 16.2 & 2.50 & 0.114 \\
\hline Sex partner/spouse & 24 & 4.1 & 41 & 12.0 & 65 & 7.0 & 20.46 & 0.001 \\
\hline Television & 36 & 6.2 & 20 & 5.8 & 56 & 6.0 & 0.04 & 0.842 \\
\hline Newspaper & 13 & 2.2 & 6 & 1.7 & 19 & 2.0 & 0.24 & 0.623 \\
\hline Telephone hotline & 1 & 0.2 & 18 & 5.2 & 19 & 2.0 & 27.79 & 0.001 \\
\hline Radio & 15 & 2.6 & 3 & 0.9 & 18 & 1.9 & 3.25 & 0.072 \\
\hline Other & 143 & 24.4 & 15 & 4.4 & 158 & 17.0 & 61.66 & 0.001 \\
\hline
\end{tabular}




\begin{tabular}{|c|c|c|c|c|c|c|}
\hline \multirow[t]{2}{*}{ Variable } & \multicolumn{2}{|c|}{ Males $(n=759)$} & \multicolumn{2}{|c|}{ Females $(n=169)$} & \multirow[t]{2}{*}{$x^{2}$-value } & \multirow[t]{2}{*}{$P$-value } \\
\hline & No. & $\%$ & No. & $\%$ & & \\
\hline \multicolumn{7}{|l|}{ Motives for using the service } \\
\hline Risky sexual behaviour & 298 & 39.3 & 19 & 11.2 & 48.25 & 0.001 \\
\hline Previous blood transfusion & 169 & 22.3 & 38 & 22.5 & 0.004 & 0.951 \\
\hline Planning to get married & 120 & 15.8 & 23 & 13.6 & 0.51 & 0.474 \\
\hline Injecting drug user & 129 & 17.0 & 2 & 1.2 & 28.51 & 0.001 \\
\hline New sexual partner & 122 & 16.1 & 7 & 4.1 & 16.44 & 0.001 \\
\hline Partner has risky sexual behaviour & 56 & 7.4 & 57 & 33.7 & 89.74 & 0.001 \\
\hline Referred by health worker & 65 & 8.6 & 15 & 8.9 & 0.02 & 0.896 \\
\hline Previous HIV testing & 29 & 3.8 & 8 & 4.7 & 0.30 & 0.583 \\
\hline Other & 47 & 6.2 & 43 & 25.4 & 58.50 & 0.001 \\
\hline \multicolumn{7}{|l|}{ Source of information about VCT } \\
\hline Relative/friend & 243 & 32.0 & 60 & 35.5 & 0.76 & 0.382 \\
\hline Poster & 183 & 24.1 & 44 & 26.0 & 0.28 & 0.599 \\
\hline Health worker & 172 & 22.7 & 45 & 26.6 & 1.21 & 0.271 \\
\hline Lecture & 155 & 20.4 & 31 & 18.3 & 0.37 & 0.542 \\
\hline Another VCT client & 163 & 21.5 & 17 & 10.1 & 11.52 & 0.001 \\
\hline Pamphlet & 130 & 17.1 & 20 & 11.8 & 2.86 & 0.091 \\
\hline Sex partner/spouse & 52 & 6.9 & 13 & 7.7 & 0.15 & 0.698 \\
\hline Television & 47 & 6.2 & 9 & 5.3 & 0.18 & 0.669 \\
\hline Newspaper & 15 & 2.0 & 4 & 2.4 & 0.11 & 0.746 \\
\hline Telephone hotline & 16 & 2.1 & 3 & 1.8 & 0.08 & 0.782 \\
\hline Radio & 13 & 1.7 & 5 & 3.0 & 1.13 & 0.288 \\
\hline Other & 139 & 18.3 & 19 & 11.2 & 4.89 & 0.027 \\
\hline
\end{tabular}

at mobile centres, this percentage was $49.9 \%$ which was significantly lower than $76.7 \%$ at fixed centres $(P<0.001)$. Clients' satisfaction of most items of the counselling session was significantly higher at fixed centres compared with mobile ones.

\section{Discussion}

According to the United Nations Joint Programme on HIV/AIDS only 10\% of HIV infected individuals worldwide are aware of their HIV status [1]. The present study evaluated the rate and causes of attendance of clients at both mobile and fixed VCT centres, the characteristics of these clients and their satisfaction with the services. The study also highlighted some factors that could impede or enhance the quality of counselling and achievement of the objectives of VCT.

The present study revealed that the uptake of VCT services was low, especially at fixed centres. Many studies have suggested multiple reasons for low uptake of VCT services, including fear of stigma, marital disharmony, the incurable nature of the disease [4], perception of personal HIV risk, feeling healthy and strong [5] and sometimes fear of positive results [6]. Mobile centres may be more successful as they bring VCT services right into the community [7] and because in Egypt mobile centres offer hepatitis B and C tests, which are needed more by people. The perception that fixed VCT locations lacked privacy and confidentiality and were stigmatizing has been identified as one of the major barriers to uptake of HIV counselling and testing [8].
Community-based health education programmes are an effective method for improving and promoting acceptance of VCT, as documented by other studies [9,10]; for example, a significant increase was noted in the use of VCT services immediately after implementation of a brief STI/HIV education programme [10].

We found that the majority of VCT clients were young males. Previous studies in other countries showed that the most vulnerable group for HIV/AIDS infection are those aged 20-40 years, especially males who have risky behaviours [11-13]. In contrast, Qiang et al. in California found lower HIV testing rates among younger ages [14], while another study showed that age was not significantly associated with seeking VCT services [15]. The mean age of clients at fixed centres was significantly 


\begin{tabular}{|c|c|c|c|c|c|c|c|c|}
\hline \multirow[t]{2}{*}{ Variable } & \multicolumn{2}{|c|}{ Mobile VCT $(n=585)$} & \multicolumn{2}{|c|}{ Fixed VCT $(n=343)$} & \multicolumn{2}{|c|}{ Total $(n=928)$} & \multirow[t]{2}{*}{$x^{2}$-value } & \multirow[t]{2}{*}{$P$-value } \\
\hline & No. & $\%$ & No. & $\%$ & No. & $\%$ & & \\
\hline \multicolumn{9}{|l|}{ Service required } \\
\hline Counselling only & 69 & 11.8 & 19 & 5.5 & 88 & 9.5 & \multirow[t]{2}{*}{9.86} & \multirow[t]{2}{*}{0.002} \\
\hline Counselling and testing & 516 & 88.2 & 324 & 94.5 & 840 & 90.5 & & \\
\hline \multicolumn{9}{|l|}{ Client counselled as: } \\
\hline Individual & 574 & 98.1 & 325 & 94.8 & 899 & 96.9 & \multirow[t]{2}{*}{8.10} & \multirow[t]{2}{*}{0.004} \\
\hline Couple & 11 & 1.9 & 18 & 5.2 & 29 & 3.1 & & \\
\hline \multicolumn{9}{|l|}{ Previous HIV testing } \\
\hline None & 556 & 95.0 & 278 & 81.0 & 834 & 89.9 & \multirow[t]{4}{*}{$44.98^{\mathrm{a}}$} & \multirow[t]{4}{*}{0.001} \\
\hline Yes and negative & 27 & 4.6 & 53 & 15.5 & 80 & 8.6 & & \\
\hline Yes and positive & 0 & 0.0 & 10 & 2.9 & 10 & 1.1 & & \\
\hline Yes but don't know the result & 2 & 0.3 & 2 & 0.6 & 4 & 0.4 & & \\
\hline \multicolumn{9}{|l|}{ Health education received } \\
\hline $\begin{array}{l}\text { IEC materials available } \\
\text { in waiting room }\end{array}$ & 419 & 71.6 & 317 & 92.4 & 736 & 79.3 & 56.99 & 0.001 \\
\hline $\begin{array}{l}\text { Received health education } \\
\text { while waiting }\end{array}$ & 558 & 95.4 & 213 & 62.1 & 771 & 83.1 & 170.43 & 0.001 \\
\hline
\end{tabular}

${ }^{a}$ Comparison of none versus all yes categories.

IEC = information, education and communication.

lower than that at mobile ones in our study. In Mali a study reported that younger people were more likely to come to mobile services than fixed ones [16].

Two-thirds of all VCT clients in our study had secondary or university education. However, at mobile centres, relatively more clients were illiterate or had basic literacy than at fixed centres where clients were better educated. Well-educated people may have better awareness and motivation about the importance of VCT services for prevention of HIV/AIDS, whereas less educated people may have less awareness, and only accept VCT when mobile services reach their area free-of-charge and without effort [14]. This is in agreement with Kawichai et al. in Thailand, who showed that a higher level of education was a

\begin{tabular}{|c|c|c|c|c|}
\hline \multirow[t]{2}{*}{ Variable } & \multicolumn{2}{|c|}{ Level of satisfaction as \% of total } & \multirow[t]{2}{*}{$t$-value } & \multirow[t]{2}{*}{$P$-value } \\
\hline & Range & Mean (SD) & & \\
\hline \multicolumn{5}{|l|}{ Age (years) } \\
\hline$\leq 25$ & $37-100$ & $90.0(9.2)$ & 1.31 & 0.192 \\
\hline$>25$ & $46-100$ & $90.7(8.1)$ & & \\
\hline \multicolumn{5}{|l|}{ Sex } \\
\hline Male & $46-100$ & $90.8(8.0)$ & 2.17 & 0.031 \\
\hline Female & $37-100$ & $89.0(10.4)$ & & \\
\hline \multicolumn{5}{|c|}{ Educational level ${ }^{a}$} \\
\hline Lower & $46-100$ & $89.2(9.0)$ & 3.05 & 0.002 \\
\hline Higher & $37-100$ & $91.1(8.2)$ & & \\
\hline \multicolumn{5}{|l|}{ Marital status } \\
\hline Married & $37-100$ & $90.7(8.8)$ & 0.71 & 0.477 \\
\hline Not married & $42-100$ & $90.3(8.3)$ & & \\
\hline \multicolumn{5}{|l|}{ Type of centre } \\
\hline Mobile & $37-100$ & $88.3(8.9)$ & 11.79 & 0.001 \\
\hline Fixed & $58-100$ & $94.2(6.2)$ & & \\
\hline
\end{tabular}

${ }^{a}$ Lower education: illiterate up to primary; higher education: secondary and university. $S D=$ standard deviation. 


\begin{tabular}{|c|c|c|c|c|c|c|c|c|}
\hline \multirow[t]{2}{*}{ Variable } & \multicolumn{2}{|c|}{$\begin{array}{l}\text { Mobile VCT }(n= \\
585)\end{array}$} & \multicolumn{2}{|c|}{ Fixed VCT $(n=343)$} & \multicolumn{2}{|c|}{ Total $(n=928)$} & \multirow[t]{2}{*}{$x^{2}$-value } & \multirow[t]{2}{*}{$P$-value } \\
\hline & No. & $\%$ & No. & $\%$ & No. & $\%$ & & \\
\hline $\begin{array}{l}\text { Overall the services I received were } \\
\text { satisfactory }\end{array}$ & 578 & 98.8 & 338 & 98.5 & 916 & 98.7 & $\mathrm{FE}$ & 0.768 \\
\hline $\begin{array}{l}\text { A staff member greeted me on my } \\
\text { arrival }\end{array}$ & 564 & 96.4 & 337 & 98.3 & 901 & 97.1 & 2.59 & 0.107 \\
\hline $\begin{array}{l}\text { I was able to see someone within } 30 \\
\text { minutes of arrival }\end{array}$ & 559 & 95.6 & 334 & 97.4 & 893 & 96.2 & 1.98 & 0.160 \\
\hline I had a place to sit while I was waiting & 525 & 89.7 & 343 & 100.0 & 868 & 93.5 & 37.61 & 0.001 \\
\hline $\begin{array}{l}\text { The counsellor greeted me when I saw } \\
\mathrm{him} / \mathrm{her}\end{array}$ & 573 & 97.9 & 343 & 100.0 & 916 & 98.7 & $\mathrm{FE}$ & 0.005 \\
\hline $\begin{array}{l}\text { The counsellor introduced himself to } \\
\text { me and gave his/her name }\end{array}$ & 515 & 88.0 & 327 & 95.3 & 842 & 90.7 & 13.71 & 0.001 \\
\hline The counsellor listened actively to me & 568 & 97.1 & 343 & 100.0 & 911 & 98.2 & 10.15 & 0.001 \\
\hline $\begin{array}{l}\text { The counsellor summarized the main } \\
\text { issues discussed }\end{array}$ & 542 & 92.6 & 339 & 98.8 & 881 & 94.9 & 17.20 & 0.001 \\
\hline $\begin{array}{l}\text { The counsellor repeated and reinforced } \\
\text { important information }\end{array}$ & 536 & 91.6 & 336 & 98.0 & 872 & 94.0 & 15.31 & 0.001 \\
\hline $\begin{array}{l}\text { I talked about having an HIV test with } \\
\text { my counsellor }\end{array}$ & 544 & 93.0 & 337 & 98.3 & 881 & 94.9 & 12.44 & 0.001 \\
\hline $\begin{array}{l}\text { The counsellor gave me time to absorb } \\
\text { information and to respond }\end{array}$ & 551 & 94.2 & 337 & 98.3 & 888 & 95.7 & 8.65 & 0.003 \\
\hline $\begin{array}{l}\text { The counsellor gave me information in } \\
\text { clear and simple terms }\end{array}$ & 569 & 97.3 & 340 & 99.1 & 909 & 98.0 & 3.73 & 0.053 \\
\hline $\begin{array}{l}\text { The counsellor had up-to-date } \\
\text { knowledge about HIV }\end{array}$ & 561 & 95.9 & 334 & 97.4 & 895 & 96.4 & 1.38 & 0.240 \\
\hline $\begin{array}{l}\text { The counsellor talked about sensitive } \\
\text { issues plainly and appropriately to the } \\
\text { culture }\end{array}$ & 559 & 95.6 & 338 & 98.5 & 897 & 96.7 & 5.97 & 0.015 \\
\hline $\begin{array}{l}\text { I talked about having HIV test with my } \\
\text { counsellor }\end{array}$ & 523 & 89.4 & 338 & 98.5 & 861 & 92.8 & 26.97 & 0.001 \\
\hline $\begin{array}{l}\text { I talked about receiving HIV test result } \\
\text { with my counsellor }\end{array}$ & 505 & 86.3 & 326 & 95.0 & 831 & 89.5 & 17.56 & 0.001 \\
\hline $\begin{array}{l}\text { I talked about issues arising from } \\
\text { previous and/or current HIV testing }\end{array}$ & 300 & 51.3 & 237 & 69.1 & 537 & 57.9 & 28.14 & 0.001 \\
\hline $\begin{array}{l}\text { The counsellor made me comfortable } \\
\text { talking to him/her }\end{array}$ & 569 & 97.3 & 341 & 99.4 & 910 & 98.1 & 5.26 & 0.022 \\
\hline $\begin{array}{l}\text { I felt that the confidentiality of my test } \\
\text { results/information was well guarded }\end{array}$ & 581 & 99.3 & 343 & 100.0 & 924 & 99.6 & FE & 0.303 \\
\hline $\begin{array}{l}\text { I felt all my questions were welcomed } \\
\text { and answered }\end{array}$ & 570 & 97.4 & 338 & 98.5 & 908 & 97.8 & 1.26 & 0.263 \\
\hline $\begin{array}{l}\text { I gained practical guidance on dealing } \\
\text { with HIV/AIDS issues }\end{array}$ & 513 & 87.7 & 338 & 98.5 & 851 & 91.7 & 33.45 & 0.001 \\
\hline $\begin{array}{l}\text { I intend to discuss my test results with } \\
\text { my partner }\end{array}$ & 218 & 37.3 & 166 & 48.4 & 384 & 41.4 & 11.05 & 0.001 \\
\hline $\begin{array}{l}\text { I learnt something new from the video } \\
\text { and/or the brochures in the waiting } \\
\text { room }\end{array}$ & 292 & 49.9 & 263 & 76.7 & 555 & 59.8 & 64.42 & 0.001 \\
\hline I intend to tell others about this service & 580 & 99.1 & 336 & 98.0 & 916 & 98.7 & 2.38 & 0.123 \\
\hline
\end{tabular}

$F E=$ Fisher exact test. 
factor associated with having a previous HIV test [17]. Skilled workers were the main occupational group served in the present study. In mobile centres, relatively more manual workers, students and employees were served. Moulaye et al. found that students used mobile services more than fixed ones [16].

In the present study males were more likely to seek VCT services because of having risky sexual behaviour or being injecting drug users than did females. This may be because males in Egypt have more opportunities than females for risky sexual behaviour. Also males may be exposed to more peer pressure and opportunities to use drugs [18]. However, the sex of those using the service might also be affected by the lack of female counsellors in the VCT or by differences between males and females in health-seeking behaviour.

In our study, the main sources of information about VCT services were relatives/friends, while radio, newspapers and the telephone hotline showed the lowest rank. Others have suggested that motivation for uptake of VCT is driven by knowledge and education rather than sexual risk [19]. Of 723 individuals served by VCT in a rural district of Malawi, the most common reason for attendance (50\%) was recent knowledge of HIV/AIDS and desire to know their HIV status. The majority of clients (77\%) underwent VCT after being encouraged by others who know their status [20]. It was found that peer education resulted in a significant reduction in the number of HIV infections [21]. In a study in Nigeria, the mass media and religious organizations were the most common sources of information about VCT [22]. Activation of these sources in our community could also increase VCT uptake.

The majority of VCT clients in our study received counselling and testing (90.5\%). Kawichai found that 95\% of respondents who had HIV testing did not receive pre- and post-test counselling [17]. Almost all our counselling and testing was done on an individual basis with only $3.1 \%$ of clients counselled as couples. In spite of the observation that VCT of couples decreased HIV incidence between parents by $50 \%$, less than $1 \%$ of African couples have been tested together [7].

Clients' satisfaction with VCT services in Egypt varied by sex, education level and type of centre. This may be explained by the fact that most of the counsellors were males, clients with better education were more aware about VCT services and that in fixed centres the services were more satisfying and comfortable to clients than in mobile ones. Colebunders et al. reported that the level of patient satisfaction was generally higher with services at university hospitals in Flanders than in general hospitals where the services were poorer [23].

In the present study there was low intention to share the test results with partners (only $41.4 \%$ ). This may be due to poor communication between partners due to traditional beliefs in our society, difficulty in discussing sensitive subjects such as sex and the roles of men and women within marriage [24]. A policy of promoting couple-oriented VCT would be more successful than individual testing [25].

There were some limitations to the study. The low rate of attendance at the mobile centres affected to some extent the representativeness of the distribution of clients between fixed and mobile centres and the research team failed to satisfy the sample size in 2 of the fixed centres. The results may suffer to some extent from interviewer bias and social desirability bias. All efforts were made to minimize these biases.

\section{Conclusion}

The level of satisfaction of clients with VCT services in this study in Egypt is considered to be high. Male sex, higher education level and attendance at fixed centres were associated with a higher level of satisfaction.

\section{Acknowledgements}

This investigation received technical and financial support from the joint WHO Eastern Mediterranean Region (EMRO), Division of Communicable Diseases (DCD) and the WHO Special Programme for Research and Training in Tropical Diseases (TDR): the EMRO/DCD/TDR Small Grants Scheme for Operational Research in Tropical and Communicable Diseases.

\section{References}

1. AIDS epidemic update, December 2005. Geneva, Joint United Nations Children's on HIV/AIDS/World Health Organization, 2005.

2. UNAIDS at country level: progress report. Geneva, Joint United Nations Children's on HIV/AIDS, 2004.

3. Lamptey RP, Gayle HD. HIV/AIDS prevention and care in resource-constrained settings: a handbook for the design and management of programs. Research Triangle Park, North Carolina, Family Health International, 2001.
4. Iliyasu Z et al. Knowledge of HIV/AIDS and attitudes towards voluntary counseling and testing among adults. Journal of the National Medical Association, 2006, 98(12):1917-22.

5. Killew JZ et al. Acceptability of voluntary HIV testing with counseling in rural village on Kagera, Tanzania. AIDS care, 1998, 10(4):431-9.

6. Ginwalla SK et al. Use of UNAIDS tools to evaluate HIV voluntary counseling and testing services for mine workers in South Africa. AIDS care, 2002, 14(5):707-26. 
7. Casanova D. Taking it to the streets: mobile units for couple voluntary counseling and testing. In: Proceedings of the $3 \mathrm{rd}$ International AIDS Society Conference on HIV Pathogenesis and Treatment, Rio de Janeiro, 24-27 July 2005 (Abstract No. TuPp0201).

8. Baiden $\mathrm{F}$ et al. Using lay counselors to promote communitybased voluntary counseling and HIV testing in rural northern Ghana: a baseline survey on community acceptance and stigma. Journal of biosocial science, 2007, 39(5):721-33.

9. Zhang JL et al. [Correlates of and willingness to participate in HIV voluntary counseling and testing among migrants in a city of Shanxi province]. Zhonghua liu xing bing xue za zhi, 2007, 28(4):350-3 [in Chinese].

10. Straub DM et al. HIV prevention education and testing among youth: is there a correlation? Journal of adolescent health, 2007, 41(1):105-7.

11. Pronyk PM et al. Introduction of voluntary counseling and rapid testing for HIV in rural South Africa: from theory to practice. AIDS care, 2002, 14(6):859-65.

12. Kosanovic ML, Kolaric B. Characteristics of clients tested for human immunodeficiency virus infection at voluntary counseling and testing center in Zagreb, Croatia. Collegium antropologicum, 2006, 30(Suppl. 2):115-9.

13. Shin SR, Hang SH, Moneyham L. Characteristics of individual seeking voluntary counseling HIV infection in South Korea. Journal of the Association of Nurses in AIDS Care, 2007, 18(5):2733.

14. Qiang X et al. HIV Prevalence and sexual risk behaviors among men who have sex with men: results from a statewide population-based survey in California. Journal of acquired immune deficiency syndromes, 2006, 41(2):238-45.

15. Marx R et al. Barriers to getting needed services for Ryan White CARE clients. AIDS care, 2001, 13(2):233-42.
16. Moulaye C, Annekatrin S. Mobile testing services for HIV/AIDS serve hard-to-reach risk groups. Bamoko, Mali, Joint United Nations Children's on HIV/AIDS, 2006.

17. Kawichai $\mathrm{S}$ et al. HIV voluntary counseling and testing and HIV incidence in male injecting drug users in northern Thailand: evidence of an urgent need for HIV prevention. Journal of acquired immune deficiency syndromes, 2006, 41(2):186-93.

18. Jassen $\mathrm{M}$ et al. Educational status and young Dutch gay men's beliefs about using condoms. AIDS care, 2001, 13(1):41-56.

19. Trujillo LA, Rhucharoenpornpani ChO, Tadashi Y. HIV testing behavior and HIV voluntary testing and counseling experiences among dense urban populations in Bangkok, Thailand. In: Proceedings of the 15th International Conference on AIDS, 11-16 July 2004, Bangkok, Thailand (Abstract no. TuPeD4981).

20. Zachariah $\mathrm{R}$ et al. Motives, sexual behavior and risk factors associated with HIV in individual seeking voluntary counseling and testing in a rural district of Malawi. Tropical doctor, 2003, 33(2):88-91.

21. Basset M. Impact of peer education on HIV infection in Zimbabwe. Sexual health exchange, 1998, (4):14-5.

22. Ikecheblu IJ et al. The knowledge, attitude and practice of voluntary counseling and testing (VCT) for HIV/AIDS among undergraduate in a polytechnic in Southeast, Nigeria. Nigerian journal of medicine, 2006, 15(3):245-9.

23. Colebunders $\mathrm{R}$ et al. Hospital services for people with HIV infection in Flanders: patient's satisfaction. AIDS care, 2001, 13(2):191-6.

24. Baggaley A et al. HIV counselling and testing in Zambia: the Kara counselling experience. SAfAIDS news, 1998, 6(2):1-9.

25. Glick P. Scaling up HIV voluntary counseling and testing in Africa: what can evaluation studies tell us about potential prevention impacts? Evaluation review, 2005, 29(4):331-57. 